\title{
Constraints to adoption of fish farming technologies among fish farmers in Obio/Akpor Local Government Area of Rivers State, Nigeria
}

$*^{1}$ Ogunremi, J. B. and ${ }^{2}$ S.O. Olatunji

${ }^{I}$ Department of Fisheries and Aquaculture, Federal University Wukari, Taraba State, Nigeria.

${ }^{2}$ Department of Agricultural Economics and Extension, University of Port Harcourt, Nigeria.

Abstract Corresponding author*jogunremi@gmail.com +234 8102650455

In the study the adoption of improved fish farming technologies in Obio/Akpor Local Government Area of Rivers State was investigated. Multistage sampling technique was used. The first stage was purposive selection of seven communities, the next stage was snowball sampling technique used to select 10 fish farmers from each community. Data were collected using structured questionnaire and analyzed using descriptive statistics. The results indicated that majority of fish farmers were aware of fish farming technologies (91.4\%). The respondents adopted the facilities for improved fish farming (21.0\%), liming techniques (14.3\%), and fish culture management (11.4\%). Constraints to farmers' adoption of fish farming technologies are high cost of improved technologies (mean $=3.39$ ), inadequate capital (mean $=3.35)$, erratic- power supply (mean $=3.12)$ and inaccessibility to credit facilities (mean $=3.11)$. It is recommended that agricultural credit schemes be strengthened at all levels, power supply be improved on, marketing structure should be well organized and extension services should be focused on which will enhance high level of technology adoption and result in much anticipated reduction in fish importation through fish farming in the country.

Keywords: Adoption, constraints, fish farmers, fish farming, technologies

\section{Introduction}

Fish from both natural sources and aquaculture are an important source of highly nutritive food, source of employment and of economic benefit. Fish products are important in human diet because of their digestibility and high nutritional value, mostly characterized by the presence of high quality proteins (contributes about $60 \%$ of the world's supply of protein while $60 \%$ of the developing countries derive $30 \%$ of their annual protein from fish (Abisoye et al., 2001).

Fishery continues to maintain its crucial position through its contribution to the agriculture's share of gross domestic product (GDP) in Nigeria. Fishery subsector was reported to have contributed an average of about $10 \%$ of agricultural GDP between 2008 and 2012 (Food and
Agriculture Organization - FAO, 2013). The huge drain on Nigeria scarce foreign exchange through fish importation can be reversed through increased fish production in the country (Olatunji and Ogunremi, 2016).

Despite the abundant human and nonhuman resources that the nation is blessed with, the country is yet to bridge the gap between the demand and supply of fish, thereby making the nation one of the protein deficient nations. The development of aquaculture can only be enhanced by the introduction of modern technologies (Ogunremi and Oladele, 2012). There are human and natural resources in Nigeria which if properly harnessed can boost aquaculture production there by crating job opportunities for the youth, development of rural areas, reduction in rural urban movement, income earning and increase in 


\section{Constraints to adoption of fish farming technologies}

protein supply to the populace. It is believed that aquaculture has the tendency to contribute significantly to the local fish production in the country if improved technologies are adopted by the fish farmers (Olaoye et al., 2016). Wellarticulated technologies is crucial to substantial aquaculture development in the world especially a developing economy like Nigeria where majority of the fish farmers could not produce to the maximum capacity of their farms because of lack of understanding of potentials embedded in aquaculture technologies or inadequate information. The technologies used by most Nigerian fish farmers are relatively simple, often based on small modifications that improve the growth and survival rates of the target species, improving feed, fish seeds, oxygen levels and protection from predators (Salau et al., 2014). Adoption of technology can be described as innovation decision process where an innovation passes through the time of first knowledge of the innovation to the decision stage of adoption or rejection and to confirmation of that decision (Ekong, 2002). The adoptionrejection decision of the farmer is, to a larger extent, dependent on the degree of risk involved relative to the existing practices (Susan and Peter, 2014).

The major role of extension agents is dissemination of various technologies aimed at boosting productivity of fish farmers through maximum adoption level. The objective of the study was to determine the constraints to adoption of fish farming technologies among fish farmers in Obio/Akpor Local Government Area (LGA) in the metropolis of Port Harcourt, Rivers State, Nigeria.

\section{Materials and methods Area of study}

The study was carried out in Obio/Akpor LGA in the metropolis of Port Harcourt, one of the major cities of Niger Delta, located in Rivers State. The LGA covers $260 \mathrm{~km}^{2}$ and at the 2006 census held a population of 464,789. Obio/Akpor is bounded by Port Harcourt to the south, Oyigbo to the east, Ikwerre to the North and Emuoha to the west. It is located between the latitude $4^{\circ}, 45^{\prime} \mathrm{N}$ and $4^{\circ} 60^{\prime} \mathrm{N}$ and longitude $6^{\circ} 50^{\prime} \mathrm{E}$ and $8^{\circ} 00^{\prime} \mathrm{E}$ it is mainly made up by people of Ikwerre ethnic nationality. The major occupations of the people are arable crop farmers, trading and fishing. Obio/Akpor has a total number of three kingdoms which are Apara, Evo and Akpor Kingdom from which 54 communities are found. ("Obio/Akpor geographical location,” 2017)

\section{Sampling procedure}

Multistage sampling technique was used to select respondents for the study. The first stage was a purposive sampling of seven communities that have more fish farmers than the others. The next stage involved the use of snowball sampling technique to select (10) fish farmers in each of the seven selected communities. Thus the total population size was 70 fish farmers.

\section{Data collection and method of analysis}

Questionnaire was used for data collection and supplemented with scheduled interview where respondents were illiterates. Constraints to adoption of fish farming technologies was achieved by rating respondents on 4-point Likert scale of strongly agree $=4$, agree $=3$, disagree $=2$, and strongly disagree $=1$, based on their responses to the questionnaire. Data collected were analyzed using descriptive statistics mean, percentage and ranking.

\section{Results and discussion}

Table 1 showed that $91.4 \%$ were aware of fish farming technologies, while minorities of $7.1 \%$ were not aware of the improved technologies. Creating awareness on fish farming technologies could be attributed to 


\section{Ogunremi and Olatunji}

interest of various groups governmental, non- governmental and individuals on the need to increase fish production because of benefits attached to it. Awareness is the first stage in the process of adoption of any innovation (Olatunji and Ogunremi, 2016).

Table 1: Awareness of fish farming technologies

\begin{tabular}{lll}
\hline Variables & Frequency & Percentage (\%) \\
\hline Yes & 64.0 & 91.4 \\
No & 5.0 & 7.1 \\
No response & 1.0 & 1.4 \\
TOTAL & $\mathbf{7 0}$ & $\mathbf{1 0 0}$ \\
\hline
\end{tabular}

Source: field survey 2017

Table 2 showed the fish farming technologies that fish farmers were aware of the results indicated that $75.8 \%$ were aware of some of the technologies listed in the interview schedule, $41.4 \%$ were aware of treatment against diseases, $35.7 \%$ were aware of fish feed improvement and water quality management, $31.4 \%$ were aware of facilities for improved fish farming while the least awareness of $1.4 \%$ were on fish feed improvement and integrated fish farming. Accessibility among other things accounts for the awareness of fish farmers to some of the available technologies.
Development of improved technologies must be backed up with efficient dissemination to enhance its adoption (Adesehinwa, and Bolorunduro, 2007). High level of awareness on treatment of diseases is important because no matter the level of fish production if disease out- break of fish diseases is not well handled it could lead to loss for the fish farmers. Fish feed improvement and water quality management is equally important in fish production, their understanding and effective utilization contributes maximally to fish farming in terms of out- put.

Table 2: Awareness of fish farming technologies

\begin{tabular}{lll}
\hline Variables & Frequency* & Percentage (\%) \\
\hline All the technologies & 15 & 21.4 \\
Fish feed improvement & 1 & 1.4 \\
Integrated fish farming & 1 & 1.4 \\
Some of the technologies & 53 & 75.8 \\
Facilities for improved fish farming & 22 & 31.4 \\
Fish feed improvement & 25 & 35.7 \\
Genetically modified tilapia & 10 & 14.3 \\
Water quality management & 25 & 35.7 \\
Liming techniques & 15 & 21.4 \\
Fish culture management & 21 & 30.0 \\
Soil testing before site selection & 12 & 17.1 \\
Improved breeds of fingerlings & 20 & 28.6 \\
Treatment against diseases & 29 & 41.4 \\
Integrated fish farming & 16 & 22.9 \\
Standard feeding regimes & 19 & 27.1 \\
Record keeping & 17 & 24.3 \\
\hline
\end{tabular}

Source: field survey, 2017

* Are multiple responses 


\section{Constraints to adoption of fish farming technologies}

Table 3 showed that $21.0 \%$ of respondents adopted the facilities for improved fish farming, $14.3 \%$ liming techniques, 11.4 fish culture management, $10 \%$ adopted water quality management and $8.6 \%$ adopted the soil testing before site selection technique while the least adopted was standard feeding regime of $1.4 \%$. All technologies fish farmers were aware of were adopted at low level which is an indication that high level of awareness is not a guarantee for high adoption rate as reported by Odediran and Ojebiyi (2017).
There are several factors responsible for decision on adoption of technology which could be internal within the reach of fish farmer or external beyond his reach. The accept-reject decision of an innovation depends on an individual farmer who engaged in farming activities (Mawusi, 2004). The innovations can be adopted at a very slow pace because farmers had to make their choices on which innovations they wanted to practice in relation to their fish farming situations, given the limited resources they have and constraints faced (Wetengere, 2008).

Table 3: Fish farming technologies adopted by fish farmers

\begin{tabular}{lll}
\hline Variables & Frequency* & Percentage\% \\
\hline Facilities for improved fish farming & 15 & 21.0 \\
Standard feeding regime & 1 & 1.4 \\
Fish feed improvement & 2 & 2.9 \\
Genetically modified tilapia & 2 & 2.9 \\
Water quality management & 7 & 10.0 \\
Liming technique & 10 & 14.3 \\
Fish culture management & 9 & 11.4 \\
Soil testing before site selection & 6 & 8.6 \\
Improved breeds of fingerlings & 2 & 2.9 \\
Facilities for improved fish farming & 4 & 5.7 \\
Genetically modified tilapia & 4 & 5.7 \\
Water quality and quantity management & 3 & 4.3 \\
Soil testing before site selection & 4 & 5.7 \\
Improved breeds of fingerlings & 2 & 2.9 \\
Treatment against disease & 2 & 2.9 \\
Integrated fish farming & 2 & 2.9 \\
\hline
\end{tabular}

Source: field survey, 2017

* Are multiple responses

The results in Table 4 showed constraints to fish farmers' adoption of improved fish farming technologies in the study area, those accepted were considered as major constraints while those rejected were classified as non-major. High cost of improved technologies (mean $=3.39$ ) was an indication that the technologies were mostly foreign and are affected by exchange rate which is not fixed. Inadequate capital $($ mean $=3.5)$ in line with the research of Salau, Lewee, Luka and Bello (2014), Adefalu et al. (2013) and Issa et al. (2014) revealed that inadequate capital was the major constraints to adoption of improved fisheries technologies by fish farmers. Inadequate or erratic- power supply (mean $=3.12$ ) limits adoption, not many farmers could afford cost of generating sets, fuelling and maintenance. Inaccessibility to credit facility (mean $=3.11$ ), collateral security, bureaucracy and peasant nature of some farmers limits fish farmers in technology adoption. High cost of feed (mean $=3.00)$ as a constraint explains why some fish farmers could not afford the purchase of 


\section{Ogunremi and Olatunji}

feed that could have boosted their production. In a similar study, (Ojo and Egeonu 2017) reported scarcity of fish feeds and their costly nature responsible for non-adoption of technologies. Nwachukwu and Onuegbu (2007) had noted that feeding was always a problem because farmers were not always able to afford the cost of the feed. Poor marketing structure $($ mean $=2.96)$ signifies problem sometimes encountered by fish farmers from the middle men who exploits them, Manus and Singas (201) reported marketing facilities as a major constraint to technology adoption. High cost of land (mean $=2.91)$ also constituted constraints to adoption of technologies because in urban cities of Nigeria land is scarce which make farmers to adopt expensive systems of fish culture such as flow-through system and fibre tanks. Poor extension service (mean $=2.90)$ could be attributed to poor extension linkage system which decrease the rate of technology adoption among fish farmers. Agwu et al (2007) alleged that high extension agents' farmer ratio would obviously affect effectiveness and efficiency of extension delivery in the rural areas. The studies also showed that extension agents were not very knowledgeable about most of the innovative technologies and do not effectively monitor the fish farmers to ensure adoption. Scarcity of labour (mean = 2.57) as constraint to adoption of fish farming technologies has led to fold up of some farms because some technologies require the skilled labour for its utilization.

Table 4: The constraints to fish farmers' adoption of fish farming technologies

\begin{tabular}{lll}
\hline Factors as perceived by fish farmers & Mean $(\overline{\mathbf{x}})$ & Remarks \\
\hline Problem of technology dissemination & 1.97 & Rejects \\
Inaccessibility to credit facility & 3.11 & Accepts \\
high costs of technologies & 3.39 & Accepts \\
erratic power supply & 3.12 & Accepts \\
health challenges & 1.84 & Rejects \\
inadequate entrepreneur skill & 1.96 & Rejects \\
Preference for wild fish to cultured fish & 2.25 & Rejects \\
Poor marketing structure & 2.96 & Accepts \\
Inadequate capital & 3.35 & Accepts \\
High cost of feed & 3.00 & Accepts \\
High cost of land & 2.91 & Accepts \\
Problems of predators & 2.01 & Rejects \\
Disease outbreak & 1.99 & Rejects \\
Poor extension service & 2.90 & Accepts \\
Educational level & 1.84 & Rejects \\
Scarcity of labour & 2.57 & Accepts \\
\hline
\end{tabular}

Source: field survey 2017

Mean score $\geq 2.5$ suggest accept.

\section{Conclusion}

The study indicated that there was generally high level of awareness of fish farming technologies but the adoption level was low due to many constraints that affected the farmers. Among these were high cost of technologies, inadequate capital, erratic power supply, high cost of feeds and high cost of land. It is recommended that agricultural credit schemes be strengthened at all levels, power supply be improved on, marketing structure should be well organized and extension services should be focused on which will enhance high level of technology adoption and result in much 


\section{Constraints to adoption of fish farming technologies}

anticipated reduction in fish importation through fish farming in the country.

References

Abisoye, B. F., Ojo, S. K. S., Adeyemi, R. S. and Olajuyigbe, O. O. 2011. Bacteriological assessment of some commonly sold fishes in Lagos metropolis market Nigeria. Prim. J.Microbiol. Res, 1(2) pp. 23-26.

Adefalu, L. L., Aderinoye-Abdulwahab., S. A., Bello, O. G., Olorunfemi, O. D. and Oba, S. A. 2013. Information Needs of Fish Farmers in Ilorin Metropolis, Kwara State Nigeria. Nigerian Journal of Agriculture, Food and Environment 9(2) pp1-5

Adesehinwa., A. O. K. And Bolorunduro, P. I. 2007. Existing fisheries technologies and approaches for dissemination in two maritime States of Nigeria: Effectiveness and constraints. American-Eur. J. Agr. Enviro. Sci., 2(3) pp 231-239

Agwu, A. E., Uche-Mba, U. C. and Akinnagbe, O. M. 2008. Use of Information Communication Technology (ICTs) among Researchers, Extension Workers and Farmers in Abia and Enugu States: Implications for a National Agricultural Extension Policy. Journal of Agricultural Extension.12 (1) pp 16-22

Ekong, E. E. 2002. An Introduction to Rural Sociology, Jumak Publisher, Nigeria.Handbook on small-scale freshwater fish farming, Rome pp 56

Food and Agriculture Organization FAO 2013. FAO country programming framework (CPF). Federal Republic of Nigeria, Fiat Panis, 1-41.
Issa, F. O., Abdulazeez, M. O., Kezi, D. M., Dare, J. S. and Umar, R. 2014. Profitability analysis of small scale catfish farming in Kaduna State Nigeria, Journal of Agricultural Extension and Rural Development 6(8) pp267-273

Mawusi, B., 2004. Farmers' Knowledge and Perception towards a Sustainable Adoption of Sugar Beet in Kenya, Lund University, Swed

Manus, P. and Singas, S. 2014. Determinants of Adoption of Pond Fish Farming Innovations in Salamaua of Morobe Province in Papua New Guinea South Pacific Studies Vol.35 (1) pp 1-16

Nwachukwu, I., and Onuegbu, R. 2007. Adoption of aquaculture technology by fish farmers in Imo State of Nigeria. The Journal of Technology Studies 33(1) pp 57-64

Odediran, O.F. and Ojebiyi, W.G. 2017. Awareness and Adoption of Improved fish processing Technologies among Fish Processors in Lagos State, Nigeria. Research Journal of Agricultural and Environmental Management Vol. 6(3) pp 46-54

Ojo, U. O. and Egeonu, N. E. 2017. Effectiveness of the Transfer and Adoption of Recommended Fish Technologies in Abia State, Nigeria. Journal of Community \& Communication Research, Vol. 2(1) pp 50-55

Olaoye, O. J., Ezeri, G. N. O., AkegbejoSamsons, Y., Awotunde, J. M., Ojebiyi, W. G. (2016. Dynamics of the adoption of improved aquaculture technologies among fish farmers in Lagos State, Nigeria. Croatian Journal of Fisheries, 74 pp 56-70 


\section{Ogunremi and Olatunji}

Olatunji, S. O. and Ogunremi, J. B. 2016. Assessment of Awareness and Adoption of Fish Farming Technologies in Obio-Akpor Local Government Area of Rivers State, Nigeria. The Journal of Agricultural Sciences Vol. 11(3) pp 147-154

Ogunremi, J. B. and Oladele, O. I. 2012. Adoption of aquaculture technology by fish farmers in Lagos State, Nigeria. Life Science Journal, 9(2) pp 430-434

Salau, E. S., Lawal, A.Y., Luka, G. E. and Bello, D. 2014. Adoption of improved fisheries technologies by fish farmers in Southern Agricultural Zone of Nasarawa State, Nigeria. Journal of Agricultural Extension and Rural Development Vol.6 (11) pp 339 346
Susan, S. and Peter, M. 2014. Factors influencing adoption of Pond fish farming Innovations in Potsy of Morobe Province, Papua New Guinea. Universal Journal of Agricultural Research 2(6) pp 191197 ,

Wetengere, K. 2010. Determinants of Adoption of a Recommended Package of Fish Farming Technology: The case of Selected Villages in Eastern Tanzania. Advanced Journal of Advance Journal of Food Science and Technology 2(1) pp 55-62, 2010.

Received: $19^{\text {th }}$ September, 2018 Accepted: $10^{\text {th }}$ February, 2019 